\title{
The Comparison of Visual Appearance between Sawerigading and Hikaru Genji: Symbolism of The Buginese-Japanese Masculinity in Folklor Reconstruction
}

\author{
Ariska Edy ${ }^{1}$, Muhammad Hasyim ${ }^{2}$, Meta Sekar Puji Astuti ${ }^{3}$ \\ \{ariskaedy@gmail.com ${ }^{1}$,hasyimfrance@yahoo.com ${ }^{2}$,metadiva@gmail.com ${ }^{3}$ \} \\ Linguistic Masters Program, Faculty of Cultural Studies, Universitas Hasanuddin
}

\begin{abstract}
Some says that clothing is a reflection of the wearer's self, and in a broader sense becomes a reflection of the cultural civilization of the wearer's group. This is also reflected in the figures of Sawerigading and Hikaru Genji as cultural heroes in the two major folklores, I La Galigo and Genji Monogatari. Their visual appearance reaches an iconic level all across the country. The clothing they wear carry significance and represent the cultural characteristics of that era which are still vivid in the society's memory today. Using Barthes's semiology approach, the writer analyzes the visual appearance of Sawerigading and Hikaru Genji. Through this approach, the writer concludes that Sawerigading who represents the image of Buginese aristocratic man emphasizes more on his masculine side in order to exhibit his power and eminence. Whereas Hikaru Genji who represents the image of Japanese imperial aristocrat man leans more toward his beautiful side to show his grace and nobility.
\end{abstract}

Keywords: Sawerigading, Hikaru Genji, visual, comparison, symbol

\section{Introduction}

In every folklore that is told from generation to generation, there are certainly elements that form the aesthetic culture. From the forming elements of culture there are symbols or signs that represent how these elements can become a cultural object. Through folklore studies we are able to comprehend, study and preserve the values and ideologies contained in the cultural elements of a nation.In other words, folklore can be an important tool in reconstructing a culture.

I La Galigo[1] is one of the Bugis Folklore which is currently claimed to be the longest manuscript in the world. In the story of I La Galigo there is the figure of Sawerigading, the figure of a nobleman whose character become a symbol of mirror and hope of the real Buginese-Makassar male figure might be. The figure of Sawerigading itself is well known in Sulawesi folklore as the founding father of civilization and an adored ancestor which begins the intergenerational bloodline of kinship groups in Sulawesi. 
In the same era, in Japan there was also Genji Monogatari[2] or The Tale of Genji which is a collection of writings and diaries from a servant of the imperial palace of Japan in the tenth century. This Genji Monogatari has now been claimed as the first literary work in the world. Just like Sawerigading in I La Galigo, in the Tale of Genji there is also the figure of prince Hikaru Genji. The fame of Sawerigading and Hikaru Genji's stories has been reconstructed into various type of folklore adapted to the times, whether in story books, novels, animations, paintings, theater, even films.

The appearance of Sawerigading and Hikaru Genji is an icon that represents the nobleman figure who was the subject of women's adoration in the kingdom at that time. Both Sawerigading and Hikaru Genji are both known as lovers with home fatale qualities. Sawerigading and Genji's appearance suggests a subtle essence which become the source of their attractiveness and the way of conveying their sense of influence and power. . Departing from this idea, the writer takes the opportunity and genuine interest in conducting a research project. A number of solid research on the respective story of I La Galigo and Genji Monogatari has been carried out, despite that the writer conducts this study through making a contrasting activity at them with focus on the symbols found in the illustration of Sawerigading and Hikaru Genji from the folklore reconstruction of the story of I La Galigo and Genji Monogatari.

\section{Method}

The first step of the analysis framework in this research is to identify the visual form of Sawerigading in the story of I La Galigo and also the figure of Hikaru Genji in the story of Genji Monogatari. In this case, the author emphasizes the royal ornaments found on the Sawerigading and Hikaru Genji clothes. As for the data source, the writer not only looks at the reconstruction of the manuscript from I La Galigo and Genji Monogatari, but the writer also sees other forms of reconstruction and reconstruction as comparative material in folk theater and so on. The forms of symbols that have been found are then analyzed with Barthes's semiology approach. Barthes's semiology is a further development of Saussure's structuralism which is only in linguistic studies. However Barthes (1967-1972) then used Saussure's approach and modified it and then applied it in cultural practices.

The object of culture is to express meaning, and all these cultural practices depend on the meaning formed by the sign. According to Barthes[3], there are two sign significance systems, namely denotation and connotation. Denotation is the level of descriptive and literal meaning contained in an element of culture, in other words the level of denotation is the level of interpretation of meaning which sees a form (signifier) as its true meaning (signified). At the second level, namely connotation, where meaning is formed from the union of signs (signifier and signified) with broader cultural aspects such as beliefs, attitudes, frameworks or ideologies of social formation. When the meaning of this connotation is naturalized as something normal and natural, a myth is born. Myth makes certain views seem irrefutable because they are natural or have been destined like that. As stated by Barthes "Myth has the task of giving the historical intention a natural justification"[4] based on this thought, the writer tries to describe the visual appearance of Sawerigading and Hikaru Genji with see the connotation meaning of the signs and symbols contained in their clothes ornaments. 


\section{Results And Discussion}

In various stories, Sawerigading is always illustrated using his golden clothes that are full of gold, complete with destar and a golden keris perched on his waist. Likewise with Hikaru Genji, he always wearing his noble clothes made of layers with bright colored silk and patterned like the color of his skin which is illustrated in the following world theater portraits below,

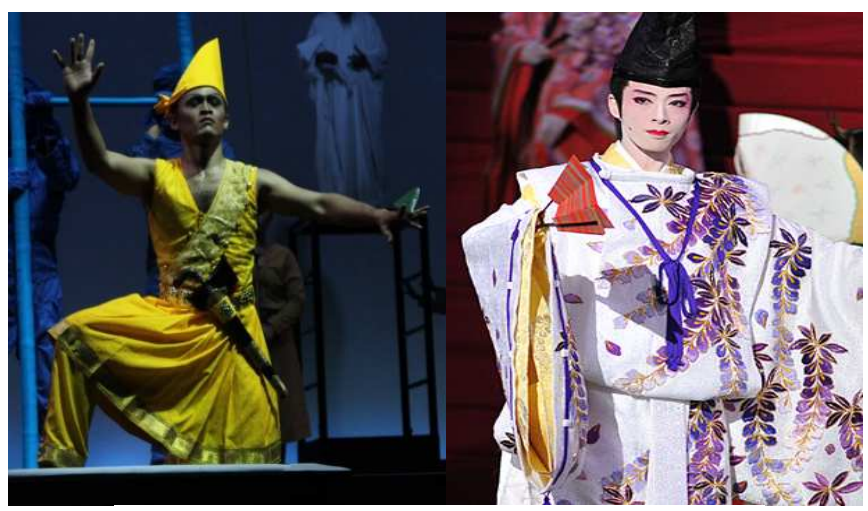

source : meikemanalagi.com / kageki.hankyu.co.jp

The two pictures above are the depictions of Sawerigading and Hikaru Genji in the theatrical performances held by two major organizers in the world. The Sawerigading story which was reconstructed into Robert Wilson's World Theater I La Galigo was staged in Makassar Indonesia in 2011[5], and also the story of Genji which was reconstructed into the The Tale of Genji Theater performed by the Japanese Takarazuka Revue Company in 2015[6].

\subsection{Vizualization of Sawerigading}

In terms of stature, Sawerigading is always told as a brave figure who since his birth has been colored by war. Sawerigading was born after the big war in the kingdom and he was born into the world complete with his golden armor. Sawerigading is depicted always wearing the golden stretchers (pajung lakkoè) and growing up in a palace environment which made of gold, and also abundant wealth of gold treasures. Therefore, gold (ulaweng) became a symbol and measure of the level of wealth and nobility of a person at that time. The yellowish color also symbolizes the greatness of the Buginese kingdom and the color of the kings itself. In Buginese, wearing the yellowish clothes, it means the wearer can represent the warm nature as the morning sun, Like gold, the wearer must be able to represent luxury but not arrogant, down to earth and not easy to be tempted with all worldly passions.

Destar (sigerra') or headband worn by Sawerigading on top of his head is likened to the comb of the rooster which can be interpreted as a symbol of fearlessness against the enemies. This symbolism is linked to the culture of Massau (Buginese-Makassar style of cockfighting) which heavily emphasizes on the masculinity, gamble of masculine dignity, and is associated with courageous quality and virility. Man at that time are considered as a brave man (tobarani) if they have the habit of drinking, good at gambling, and good at preparing rooster to cockfighting (massung manu). For furthering highlighting a man's superiority, the man has to own the strongest rooster with him on his side. Sawerigading has been consistent in maintaining those qualities in his personality, he was adept at cockfighting since early age and 
constantly wins them. Sawerigading was a renowned cockfighting athlete all across the kingdom.

The golden keris (gajang mpulaweng) which is always perched on Sawerigading's waist is a symbol of Tana Luwu's maritime and is believed to have the ability to tame the waves, deflect the wind, and tame the sea ghosts. This is also consistent with the story of Sawerigading who was able to defeat his enemies and stop the waves so the wind along his voyage to Tana Cina. A man will be considered as an adult man if his waist has been matched by a keris (maketappi pi ariwina naorowane). With a keris at the waist, they are considered as individuals who are responsible for all his actions, including responsibility for his life choices, and this is also what is held firmly by Sawerigading.

\subsection{Visualization of Hikaru Genji}

Since the beginning of the Genji Monogatari story, Hikaru Genji is recognized as a figure with natural perfection. Even when he was just born, Genji was able to astonish everyone with his handsome appearance which led him to being dubbed as the "The Shining Prince". In addition to his good looks, he is also competent at writing haiku (traditional poetry), painting, and even dancing, he is truly an embodiment of a noble figure with a high sense of artistry.

If Sawerigading always appeared with his golden ornaments, then Genji always appeared with noshi's[6] bandage. Noshi is one type of clothing in the Heian period used by members of male aristocratic families. Noshi is formed from various layers of silk cloth that reach up to the knees. The first layer is kosodè, which is the upper inner layer in the form of a short silk robe and plain white. Then shitabakama, an light inner lower layer which form like a split skirt / pants, which is also usually in color with the kosode. Then hitoè, the first layer of outwear with long sleeve collar symbolizes authority and wealth. Then sashinuki, a kind of pants layer that is hanging and reveal the feet. Sashinuki has an end rope which round the legs and be tied like a chrysanthemum flower which is a symbol of the Japanese empire and symbolizes the perfection. Then noshi was used as the main outwear with a variety of colors and motifs.

The noshi pattern and color that is usually worn by Hikaru Genji in his illustrations is designed to suit the season, nature or mood. For example, during the spring, Hikaru Genji tends to wear noshi with the color of a blossoming flower that has the accent of purplish or pink color. Purplish color symbolizes Japanese nobility at the time, while pink symbolizes youthfulness and good health. When Hikaru Genji is in a mourning or sad mood, he tends to wear dark clothes such as gray. The gray color itself in Japanese society's beliefs indicates calm, simplicity, maturity, conservativeness, old age, sadness, and boredom, not infrequently that the gray color is perceived as a color that gives an unpleasant impression. As for his usual clothing pattern, Hikaru Genji often chooses Chinese damask pattern which is the typical Chinese natural patterns that take inspiration from the plants ,flowers, ocean waves, and even animals. The use of Chinese Damask patterns indicates that Chinese influence on the Japanese empire existed at that time.

Not forgetting the èboshi, a black-colored head wrap. Èboshi itself consists of two syllables, namely $\grave{e} /$ karasu which means crow and bosh $i$ which means head covering. The crow for Japanese society is a symbol of the power and also the will / incarnation of heaven as a form of divine intervention in human affairs, this crow is one of the mythological creatures found in Shinto and Buddhist beliefs that were developing in Japanese society in that era. A stark contrast with Sawerigading who constantly brings keris with him, Hikaru Genji does not carry weapon at all. He is more fond of carrying folding fans (Sensu) compared to carrying weapons. This folding fan is not only used for convenience, but it is also used as a medium for writing information, conveying messages or symbols among other functions. 
Hikaru Genji and Sawerigading are both illustrated as male figures of royal nobility who are the image of the nobility and also the dream of every woman in their country, they however have different styles in presenting their visual appearance [13]. If observed from the style of clothes, Genji's attire more sophisticated than Sawerigading. Sawerigading's clothes are not layered, focus more on masculinity and designed to be convenient in battle. On the other hand, Genji's clothes emphasize their aesthetics more or show the art of beauty and grandeur of a nobleman.

\section{Conclusions}

The two character's daily clothing styles contain markers that are meant to highlight the status and charisma they have. Aside from their good looks and physical appearance, their style of clothing is also an attraction that is able to lure woman from the palace until the ordinary woman throughout the country.

Sawerigading's clothing style represents Buginese aristocratic men's fashion interpretation at that time. The Sawerigading piece of clothing is arguably simpler compared to Hikaru Genji. The ornaments of his clothes are meant to convey the sense of manhood and courage in the war. Apart from its cultural background, the fact that Buginese kingdom was renowned for the maritime power and associated with war between kingdoms influenced the development of his character. Thus, it can be concluded that the allure of Sawerigading as a Buginese aristocratic man is the masculine side that can be seen from his appearance to his character.

On the other hand, Hikaru Genji's clothing style represents the Heian imperial nobility at that time. His attire is more sophisticated when compared to Sawerigading, the ornaments that decorate his clothes also defines the beauty and elegance that must be owned by every royal lineage. This is also reinforced by the figure of Hikaru Genji who is well-versed at writing haiku, painting and even dancing. Thus, it can be concluded that the alluring thing of Hikaru Genji as a male imperial noble image of Japan is that the aesthetic side which is seen in his appearance and behavior. The visual appearance of Sawerigading and Genji is not only notable as a desirable ideal image to women, but also they serve as a role model for men, often time becomes an object of jealousy that can even trigger war.

From this research it can be seen that the dominance of the Buginese kingdom in that era was seen in military power which could indirectly be seen in the style of the aristocratic clothes. On the other hand in the same era, the dominance of the Japanese Empire during the Heian dynasty was seen in the arts which could be seen too in the nobility of aristocratic clothes. even the progress of the arts in the Heian dynasty was called the golden era in the history of the Japanese empire.

As closing, the existence of this paper is expected to contribute in the field of folklore and cultural studies. By reading and studying the history of culture, we will contribute to maintaining the history of our civilization so that it will not become extinct and continue to grow. 


\section{References}

[1] Kern, I La Galigo. Yogyakarta: Gadjah Mada University Press, 1989.

[2] M. Haruki, The Tale of Genji. England: Penguin Books Ltd, 1982.

[3] C. Barker, Cultural Studies. London: Sage Publication London, 2002.

[4] R. Barthes, Mythologies. New York: The Noonday Press, 1991.

[5] R. Wilson, "I La Galigo," 2011. [Online]. Available: robertwilson.com/i-la-galigo. [Accessed: 10-Aug-2019].

[6] Takarazuka, "The Tale Of Genji," 2015. [Online]. Available: https://kageki.hankyu.co.jp/english/revue/2015/genji/gallery.html. [Accessed: 10-Aug-2019].

[7] Akhmad., U. Idris, and L. Siregar, "Mitos Sawerigading dalam Epos La Galigo: Suatu Analisis Struktural," Etnosia, vol. Volume 3, no. P-ISSN: 2527-9319, E-ISSN: 2548-9747, 2018.

[8] A. Kuchta and J. Malita, "Spirit Possession and Emotional Suffering in The Tale of Genji and its selected adaptations," Kraków, no. ISBN: 978-83-63910-53-2, 2015, 2015.

[9] A. Ram, "Siri' dan Pacce dalam Perjalanan Sawerigading ke Tanah Cina," Adabiyyāt, vol. Vol. XII, 2013.

[10] H. Hosoi, T. Yamagata, Y. Ikarashi, and N. Fujisawa, "Visualization of Special Features in 'The Tale of Genji' by Text Mining and Correspondence Analysis with Clustering," J. Flow Control. Meas. Vis., no. P-ISSN: 2329-3322, E-ISSN: 2329-3330, 2014.

[11] L. Pongsibanne, Autentisitas Budaya Bugis: Jejak Sawerigading sebagai Perekat Bangsa dalam Epik I La Galigo. Yogyakarta: PT Inco Tbk, 2010.

[12] J. N. Robert, "Reflections on a Buddhist Scene in The Tale of Genji," Cipango, no. ISSN: 22681744, 2014., 2014.

[13] K. Saddhono, S. T, Widodo, M. T. Al Makmun, and M. Tozu, "The study of philosophical meaning of batik and kimono motifs to foster collaborative creative industry." Asian Soc. Sci. vol. 10 no. 9 pp 52-61, 2014 